\title{
Reconstruction of Expert Testimony For Determining The Judge Considering in The Corruption Case Based On Justice
}

\author{
Siti Nursyakirah Yuslan ${ }^{1}$ and Sera Rosanto ${ }^{2}$
}

\begin{abstract}
Calculation of state losses can only be done by an expert. Experts here are not only experts in the field of financial audit but also engineers who will calculate the feasibility of construction of a building in case of corruption was related to the construction field. Expert who has the competence do calculating the quantity of a building and the price of a building is a person who has a construction management certification. Judge in assessing the truth of the testimony / evidence, in the RIB in the know with 3 systems of evidence include3; free system (Vrij Bewijk); positive system (wettellijk) and negative cystine (wettellijk). In the formulation of Article 184 paragraph (1) Criminal Procedure Code, which specified that legal evidence is: witness testimony; expert testimony; letter; pointing and testimony of the defendant. Each handling of corruption cases, the process of calculating the amount of state losses in practice are still causing differences of interpretation either by the Prosecutor, state audit agency (BPK), the financial supervision and development (BPK), as well as the court. Description Construction Experts who have no competence in the matter of corruption, the statement becomes invalid.

Keywords: Reconstruction; Expert; Testimony; Corruption and Justice.
\end{abstract}

\section{Introduction}

Criminal law aimed at getting the material truth in revealing a criminal event. Efforts can be made to explore the material truth is through properly accounting in court. The effort is done through the evidence and the evidence to obtain a conviction on whether or not the criminal act charged, and can determine whether there is an error on the defendant himself.

According Luhut MP Pangaribuan, crime court in the Criminal Code is divided into three phases, namely the pre-adjudication, adjudication and postadjudication. Pre-adjudication phase is the phase of inquiry and / or investigation, adjudication phase is the phase of a judge in court examination, and postadjudication phase is a penal punishment ${ }^{4}$. Luhut MP Pangaribuan divide the overall activity of criminal proceedings on three (3) phases / stages, namely preadjudication phase, the phase of adjudication, and post-adjudication phase.

That means of the above evidence, which the judge did not fully recognize the truth. It depends on the judge's conviction in conducting an assessment of the

\footnotetext{
${ }^{1}$ IRKHS International Islamic University Malaysia, email: schayuslan@gmail.com

${ }^{2}$ Advocate of Semarang and Student Doctor of Law, Sultan Agung Islamic University in Semarang, email: rosantosera@gmail.com.

${ }^{3}$ M. Yahya Harahap,2010, Pembahasan Permasalahan dan Penerapan KUHAP, Sinar Grafika, Jakarta, p. 229

${ }^{4}$ Luhut M.P. Pangaribuan, 2013, Hukum Acara Pidana. Surat Resmi Advokat di Pengadilan, Papas

Sinar Sinanti, Jakarta, p. 35-36
} 
evidence. Judge in assessing the truth of the testimony / evidence, in the RIB in the know with 3 systems of evidence include5; free system (Vrij Bewijk); positive system (wettellijk) and negative cystine (wettellijk).

Each handling of corruption cases, the process of calculating the amount of state losses in practice are still causing differences of interpretation either by the Prosecutor, state audit agency (BPK), the financial supervision and development (BPK), as well as the court. Remarks experts as one type of evidence in the trial, should only be given by someone who has special expertise in accordance with the legislation must meet certain requirements, but the judge did not consider the objections the accused on the testimony of an expert in the trial that did not meet the formal requirements of expertise with Civil Code reason not regulate such things.

\section{Research Method}

This type of research is a qualitative research and the approach that used is juridical-empiric law from the standpoint of normative and legal point of view. While collecting data with literature and interview ${ }^{6}$.

\section{Discussion}

Act No. 1 of 2004 on State Treasury (Treasury Law) and Act No. 15 Of 2006 regarding the Supreme Audit Agency (UUBPK) and United Nations Against Corruption Convention, 2003 (United Nation Against Corruption, 2003) which has been ratified Indonesia through Act No. 7 of 2006. Article 1 point 22 Treasury Law and Article 1 number 15 UUBPK defined, Disadvantages Country / Region is short of money, securities, and goods, real and definite amount as a result of an unlawful act, either intentionally or careless. Base on this sense, the conception of damages adopted a conception of state losses in terms of material offense, namely an act can be said to be detrimental to the state finance, subject to their losses that actually real or actual. That conception is the same with the phrase "substantially has no loss to the state" set forth in Article 32 paragraph (1) of Corruption Act as described in the explanation that states as a loss that can already be calculated based on the findings of the authorized agency or public accountants appointed. In addition to profess not deviate from the spirit of the UN Convention on against, then when entering the state loss in a corruption offense, the loss of the country should actually have occurred or real. This is because the offense of corruption in the United Nations Convention against corruption has been spelled out clearly

\footnotetext{
${ }^{5}$ M. Yahya Harahap, 2010, Pembahasan Permasalahan dan Penerapan KUHAP, Sinar Grafika, Jakarta, p. 229

${ }^{6}$ Suharsimi Arikunto, 2002, Prosedur Penelitian, Suatu Pendekatan Praktek. Jakarta: PT Rineka Cipta, p. 67
} 
include bribery, embezzlement in office, trading in influence, abuse of office, public officials make advantages themselves unlawfully, bribery in the private sector, embezzlement in private enterprise, money laundering proceeds crime, hiding the existence of the crime of corruption, and hinder the judicial process ${ }^{7}$.

The ruling of the Constitutional Court Number: 25 / PUU-XIV / 2016, dated January 25, 2017 is as follows: Granted the request of the applicant for most; Stating the word "may" in Article 2 (1) and Article 3 of Act No. 31 of 1999 on Corruption Eradication, as amended by Act No. 20 of 2001 on the Amendment of Act No. 31 of 1999 on Eradication Corruption (Official Gazette of the Republic of Indonesia Of 2001 Number 134, Supplement to the State Gazette of the Republic of Indonesia Number 4150) is contrary to the Constitution of the Republic of Indonesia Of 1945 and have not binding legal force; Rejected the applicant apart and rest; Ordered the publication of this decision in the Official Gazette.

Based on the description as mentioned above, it can be concluded, the state adopted a conception losses in national law is actual loss which, according to the Constitutional Court give more legal certainty and consistent with efforts to synchronize and harmonize national legal instruments and international. This provides the legal consequences for law enforcement agencies, especially the public prosecutor in the trial to prove any harm to the country / region in a real and definite amount. Determination of the amount of loss to the state should be based on a system and method of calculating the appropriate state financial audit standards and not based on assumptions or estimates only,

\subsection{Expert Testimony As Evidence}

Expert testimony is the opinion of the person who was given under oath in the trial of the case is known in his experience and knowledge ${ }^{8}$. The definition refers the provisions of Article 1, point 28 Criminal Procedure Code that expert testimony is the testimony given by a person who has special expertise about the things necessary to make light of a criminal case for the purpose of examination ".

Someone is said to have or have specialized expertise, in this case a character still an abstract concept. Although even have an abstract concept, but in this case the statement of the expert was deemed paramount in order to assist law enforcement officials, especially judges in court in order to prevent the occurrence of a judicial error, whether the error in the subject, the object and the application of the law in the process of investigation and criminal justice?.

\footnotetext{
7 Friedrich, Joachim Carl ,2004, Filsafat Hukum Perspektif Historis, Nuansa dan Nusamedia : Bandung, p. 77

${ }^{8}$ Sudikno Mertokusumo, 2008, Hukum Acara Perdata Indonesia, liberty, Yogyakarta, p. 165

${ }^{9}$ Hamzah Andi, 2010, Hukum Acara Pidana, Sinar Grafika, Jakarta, p. 32
} 
Special skills mentioned in Article 1, point 28 of the Criminal Procedure Code, in that it can be interpreted with regard to the ability to explain or describe to a particular object in order to assist the criminal justice process. Ability here based on the experience, skills or knowledge possessed by the witness. The term "experience" is typically attached to the empirical world and instead the term "experience" is typically placed in the realm of theory, but did not rule one can only be regarded as having "special skills" because it bears the two professions at once, namely as a theoretical as well as practitioners ${ }^{10}$.

Viewed from above the rules in the Criminal Code ${ }^{11}$, when researched and examined where the Criminal Procedure Code does not regulate the terms specifically about what he listens to a statement of the expert in the examination in court. As called for in the Criminal Procedure Code is as long as he has a 'special expertise' about the things necessary to make light of a criminal case and submitted by certain parties, the statement could be heard for inspection ${ }^{12}$.

The presence of an expert in the hearing may be requested by the defendant, as well as the Public Prosecutor. Besides hearing the presiding judge may appoint a person or persons of experts to provide information either by mail or in writing, which was confirmed by oath or affirmation according to the truth of all knowledge and experience. Expert testimony is required to increase the confidence of judges on an issue in a particular field, that it can only be explained by an expertin the concerned field, for example an expert in the field banking, experts in the field of Public Administration, ballistics experts and others ${ }^{13}$.

Porigin subsection 184 (1) Code of Criminal Procedure ${ }^{14}$ expressly directed the expert testimony as a valid evidence, as in the formulation of Article 184 paragraph (1) Criminal Procedure Code, which specified that legal evidence is: witness testimony; expert testimony; letter; pointing and testimony of the defendant. But despite expert testimony have had a stronger position in the Criminal Code, but in the opinion of a Judge M. Yahya Harahap is not absolutely bound to a statement of the expert ${ }^{15}$. M. Yahya Harahap write about problems the strength of evidence from expert testimony as follows ${ }^{16}$ :

..., The value of the strength of evidence attached to the statement of the expert evidence has a value of strength of evidence "free" or vrij bewijskracht. In him there is no inherent value of the strength of evidence was perfect and decisive. Justice

\footnotetext{
10 Harahap Yahya M., 2005, Pembahasan Permasalahan dan Penerapan KUHAP Pemeriksaan Sidang Pengadilan, Banding, Kasasi dan Peninjauan Kembali, Sinar Grafika, Jakarta, p. 271

11 Huijbers, Theo, 2005, Filsafat Hukum dalam lintasan sejarah, cet VIII, Kanisius: Yogyakarta, p. 19

12 Chazawi Adami, 2006, Hukum Pembuktian Tindak Pidana Korupsi, PT Alumni,Bandung, p. 43

13 Fanani, Ahmad Zaenal, Tanpa Tahun, Teori Keadilan dalam Perspektif Filsafat Hukum dan Islam, Paper Yogyakarta: UII, p. 126

${ }^{14}$ Fauzan Uzair dan Heru Prasetyo, 2006, Teori Keadilan, Pustaka Pelajar: Yogyakarta, p. 92

15 Ibid. p. 230

16 B.N. Marbun, 1996, Kamus Politik, Pustaka Sinar Harapan, Jakarta, p.469
} 
up to the judgment. Judges are independent and not tied to her vote. There is no requirement for the judge to have to accept the truth of the statements of experts referred to.

\subsection{Reconstruction of Expert Testimony Evidence As A Basis For Determining The Judge Considering The State Financial Loss In The Corruption Case Based On Justice}

Reconstruction has the meaning of "re" means renewal while construction" as explained above has the meaning of a system or form. BN Marbun defines in simple formulation or depiction back from existing materials and reassembled as is or the original incident. According to James P. Chaplin, Reconstruction is a psychoanalytic interpretation of data in such a way, to explain the personal development that has taken place, along with the meaning of the material that now exist for the individuals concerned ${ }^{17}$.

According to Article 4 paragraph (1) Regulation of the National Construction Services Development Board No. 4 of 2014 About the Expert Appraisal Construction Services stated: (1) Experts use values play a role in the activities of expert judgment on the incident Building Failure, Failure Construction Jobs, differences of opinion among the parties in the implementation of the Labor Contract Construction, construction dispute resolution and judicial processes. (2) Experts value can be done by 1 (one) or more Assessors Experts and in accordance with Article 4 (3), Appraisal Expert in carrying out its duties may be assisted by experts, and / or other support. (3) Experts use values in performing their duties may be assisted by experts, and / or other support.

That deals with the task of the expert appraiser, provided by Article 5 Regulation National Construction Services Development Board No. 4 of 2014 About the Expert Appraisal Construction Services Sector which states:

a. Duty of Appraisal Expert in building failure events is to provide an assessment and determination:

1) Because Failure the building;

2) Parts that are no longer functioning due to the failure of Buildings;

3) Responsible for the failure of building going on, and the degree and nature of the mistakes made;

4) Paint a mixed picture loss, and the proposed amount of compensation to be paid by the party or parties who make mistakes; and

5) Payment term losses.

b. Duty of Appraisal Expert in terms of the incidence of failure of Construction Works is to provide an assessment and recommendation:

1) Because the failure of Construction Works;

17 James P. Chaplin, 1997, Kamus Lengkap Psikologi, Raja Grafindo Persada: Jakarta, p.421 
2) Parts that are no longer functioning due to the failure of Construction Works;

3) Party of responsible for the failure of construction work going on, and the degree and nature of the mistakes made; and

4) Paint a mixed picture of losses, as well as suggested ways of failure repair construction work

c. Duty of Appraisal Expert in terms of the incidence of differences of opinion between the parties, is:

1) Contractual interpretation offered are as skilled on Construction Work Contract documents;

2) Offered are the opinion and / or research paper on the problem of differences of opinion to reach an agreement;

3) Completion of the proposals offered are to reach an agreement; and / or

4) Formulate the agreement of the parties.

d. Duty of Appraisal Expert in terms of the incidence of dispute settlement construction is as Mediator or conciliator.

e. Duty of Appraisal Expert as Mediator referred to in paragraph (4) includes:

1) Facilitation of the parties in the settlement of disputes;

2) Secondary any dissent in the argument;

3) Contractual interpretation offered are as skilled on the document Employment Contract Construction; and

4) Offered are the opinion and / or research paper on dispute settlement issues to reach an agreement;

f. Duty of Appraisal Expert as a conciliator, as referred to in paragraph (4) includes:

1) Facilitation of the parties in the settlement of disputes;

2) Secondary any dissent in the argument;

3) Contractual interpretation offered are as skilled on Construction Work Contract documents;

4) Offered are the opinion and / or research paper on dispute settlement issues to reach an agreement;

5) Completion of the proposals offered are to reach an agreement; and

6) Formulate the agreement of the parties.

g. Duty of Appraisal Expert in the arbitration process and the judicial process is to provide expert testimony as an expert witness.

Under the provisions of the above it can be seen duty expert appraiser, that one of them according to the provisions of Article 5 (7) is to provide expert testimony as an expert in the judicial process. This suggests that in the field of construction services, experts who can testify in court only Appraisal Expert

\section{Conclution}


Based on the discussion in advance of exposure, it can be concluded that the testimony of experts who have the competence do calculating the quantity of a building and the price of a building is a person who has a construction management certification. Description Construction Experts who have no competence in the matter of corruption, the statement becomes invalid.

\section{References}

[1] B.N. Marbun, 1996, Kamus Politik, Pustaka Sinar Harapan, Jakarta.

[2] Chazawi Adami, 2006, Hukum Pembuktian Tindak Pidana Korupsi, PT Alumni,Bandung.

[3] Fanani, Ahmad Zaenal, Tanpa Tahun, Teori Keadilan dalam Perspektif Filsafat Hukum dan Islam, Paper Yogyakarta: UII.

[4] Fauzan Uzair dan Heru Prasetyo, 2006, Teori Keadilan, Pustaka Pelajar: Yogyakarta.

[5] Friedrich, Joachim Carl ,2004, Filsafat Hukum Perspektif Historis, Nuansa dan Nusamedia : Bandung.

[6] Hamzah Andi, 2010, Hukum Acara Pidana, Sinar Grafika, Jakarta.

[7] Harahap Yahya M., 2005, Pembahasan Permasalahan dan Penerapan KUHAP Pemeriksaan Sidang Pengadilan, Banding, Kasasi dan Peninjauan Kembali, Sinar Grafika, Jakarta.

[8] Huijbers, Theo, 2005, Filsafat Hukum dalam lintasan sejarah, cet VIII, Kanisius: Yogyakarta.

[9] James P. Chaplin, 1997, Kamus Lengkap Psikologi, Raja Grafindo Persada: Jakarta.

[10] Luhut M.P. Pangaribuan, 2013, Hukum Acara Pidana. Surat Resmi Advokat di Pengadilan, Papas Sinar Sinanti, Jakarta.

[11] M. Yahya Harahap,2010, Pembahasan Permasalahan dan Penerapan KUHAP, Sinar Grafika, Jakarta.

[12] Sudikno Mertokusumo, 2008, Hukum Acara Perdata Indonesia, liberty, Yogyakarta. 